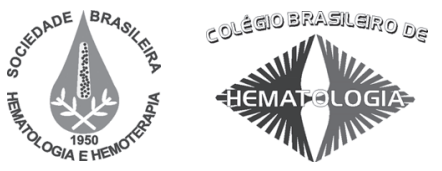

\title{
Aspectos morfológicos e imunofenotípicos das leucemias mielóides agudas em pacientes do Amazonas
}

\section{Morphological and immunophenotipical features of acute myeloid leukemias in Brazilian Amazon patients}

Eliana B. Alves

Orientadora: Mihoko Yamamoto

\section{Resumo}

As leucemias agudas são um grupo heterogêneo de doenças com incidência variável de acordo com a região estudada. O Amazonas é um estado com população sob forte influência indígena de diversas etnias e com alto índice de doenças tropicais, e a característica clinicolaboratorial das leucemias nessa região é ainda pouco conhecida. O objetivo deste trabalho foi estabelecer o diagnóstico e frequência dos subtipos FAB em pacientes com LMA atendidos consecutivamente na Fundação de Hematologia e Hemoterapia do Amazonas - Fhemoam (Manaus). O diagnóstico das LMA foi baseado nos critérios morfológicos (FAB) e a imunofenotipagem realizada pela técnica imunoenzimática EnVision System Alkaline Phosphatase ${ }^{\circledR}$ (Dako), em esfregaços de medula óssea e/ou sangue periférico, com a utilização de um amplo painel de anticorpos monoclonais. Os subtipos FAB de LMA foram analisados em relação às características clínicas e laboratoriais (morfologia, citoquímica e perfil imunofenotípico dos blastos). Entraram no estudo 62 pacientes - $25(40,3 \%)$ crianças - mediana de 6 anos e 9 meses (5m a 17a), e $37(59,7 \%)$ adultos - mediana de 30 anos (18 a 99 anos); predominou o gênero masculino (41/62-66\%). A distribuição dos subtipos FAB foi um caso M0, 12 M1 (19\%), 15 M2 (24\%), 8 M3 (13\%), 6 M4 (10\%), 15 M5 (24\%), um M6 e 4 M7 $(6 \%)$. Entre as crianças ocorreu mais M2 (32\%) e entre os adultos M5 (27\%). Três pacientes apresentaram leucemia indiferenciada, e um, bifenotípica. A faixa etária foi mais baixa em relação às LMAs descritas na literatura mundial e a menor frequência da M3 (13\%) diferiu de outros países latinoamericanos, inclusive o Brasil $(21-24 \%)$ - exceto em pacientes do Nordeste estudados por Rego et al. (7,8\%) -, aproximando-se mais de dados europeus, australianos e japoneses (9-13\%).

Palavras-chave: LMA; imunofenotipagem; Amazonas.

\begin{abstract}
Acute leukemias are a heterogeneous group of hematopoietic malignancies with variable worldwide incidences. The Amazon State has a unique population with a strong influence of native Indians from different ethnical backgrounds and with a high incidence of tropical diseases. The clinical and laboratorial characteristics of leukemia in this region are still unknown. The aim of this study was to determine the FAB subtype frequencies in acute myeloid leukemias (AML) patients consecutively diagnosed at the Hematology and Hemotherapy Foundation of Amazonas - Fhemoam (Manaus). The diagnosis of AML was based on the FAB morphological criteria and immunophenotyping using the immunoenzymatic EnVision System Alkaline Phosphatase ${ }^{\circledR}$ kit (Dako) applied on peripheral blood and/ or marrow films using an extensive panel of monoclonal antibodies. The AML FAB subtypes were evaluated in relation to the clinical and laboratorial data. A total of 62 patients were studied - $25(40.3 \%)$ children, median age of 6 years and 9 months (range: 5 months to 17 years) and $37(59.7 \%)$ adults, median age of 30 years old (18 to 99 years); there was a predominance of men (41/62-66\%). According to the FAB subtypes there were: one case of M0, 12 of M1 (19\%), 15 of M2 (24\%), 8 of M3 (13\%), 6 of M4 (10\%), 15 of M5 (24\%), one of M6 and 4 of M7 (6\%). FAB-M2 (32\%) was the most frequent subtype among children and M5 (27\%) among adults. Three patients had undifferentiated and one biphenotypic acute leukemias. Conclusions: The mean age of our AML patients was lower than those reported in the literature. The most important feature was the low frequency of M3 subtype (13\%) which was similar to the internationally reported cases (9-13\%) but different to Latin-American studies, including other Brazilian regions (21-24\%) except for one work by Rego et al. with a northeastern Brazilian population (7.8\%).
\end{abstract}

Key words: AML; immunophenotype; Amazon.

Avaliação: A RBHH publica os resumos e abstracts de teses da área apresentados em entidades que tenham programas de pós-graduação reconhecidos pelo $\mathrm{MEC/Capes} \mathrm{e} \mathrm{considera} \mathrm{a} \mathrm{obtenção} \mathrm{do} \mathrm{título}$ suficiente para sua publicação na forma como se propõe a seção.

Recebido: $01 / 10 / 2008$

Aceito: $02 / 10 / 2008$

Tese de dissertação para obtenção do título de Mestre em Ciências apresentada à Universidade Federal de São Paulo - Mestrado em Ciências Interinstitucional com a Universidade Federal do Amazonas e Fundação Hemoam.

Correspondência: Mihoko Yamamoto

Disciplina de Hematologia e Hemoterapia - Universidade Federal de São Paulo - Unifesp.

Rua Botucatu 740, $3^{\circ}$. Andar

04023-900 - São Paulo-SP - Brasil

Email:yamamoto@hemato.epm.br 